\title{
Accountability, Community Participation, And Transparency Of Public Policy Of Council Knowledge On Regional Budget And Financial Supervision (Case Study Of House Of Representatives Of Banda Aceh City)
}

\author{
Asnariza $^{1}$, Cut Hamdiah ${ }^{2}$, Sarboini $^{3}$ dan Musriadi ${ }^{4}$ \\ \{Asna_riza@yahoo.co.id ${ }^{1}$ and cut_hamdiah@yahoo.com ${ }^{2}$ \} \\ 1,2,3,4 Lecturer at the Faculty of Economics, Serambi Mekkah University, Banda Aceh, Indonesia
}

\begin{abstract}
The purpose of this study was to provide empirical evidence that budget knowledge influenced the council in the supervision of regional finances. Providing empirical evidence that accountability influenced the relationship between budget knowledge and regional financial supervision, providing empirical evidence that community participation influenced the relationship between budget knowledge and Regional financial supervision, providing empirical evidence that public policy transparency influenced the relationship between budget knowledge and regional financial supervision. This study examined the influence of accountability, community participation, and public policy transparency on the relationship between budgeting knowledge and budgeting control. The research sample was from the Banda Aceh DPRK (House of Representative of Banda Aceh). Thirty legislative members was participated in this study. This hypothesis used empirical regression. Based on the results of data analysis, it showed that all members of the council responded positively to accountability, community participation and transparency, so that it always has openness between the community and the legislative members.
\end{abstract}

Keywords: Accountability, Public Participation, Public Policy, Transparency, Budgeting Knowledge, Budgeting Control

\section{Introduction}

One of the main objectives of the government is to improve the welfare of all people. In this connection, the government strives to realize fiscal balance by maintaining the country's financial capacity derived from tax revenues and other sources in order to fulfill the people's desires. One of the important features in realizing this balance is the ongoing political process to harmonize various interests in the community.

Changes in the political system, social and community and economics brought by the current of reformation have led to diverse demands for good government governance. These demands need to be met and realized directly by the managers of local government. In line with PP No. $105 / 2000$ which was changed to PP No. 58/2005 requires the need to treat 
accountability in the form of financial statements (regional balance sheets, cash flows, and budget realization) by district heads.

The reformation fought by all levels of society brought changes in national and regional political life. One of the reformation agenda is the existence of financial decentralization and regional autonomy. Based on the Decree of the People's Consultative Assembly Number / XV / MPR / 1998 concerning the Implementation of Regional Autonomy, Regulation and Utilization of National Resources that are Equitable, and the Central and Regional Financial Balance, the government has issued a set of policies on regional autonomy, namely: Law Number 25 of 1999 concerning The financial balance between the Central and Regional Governments which was revised into Law No.33 of 2004 became the initial milestone of regional autonomy. There were significant changes in the legislative and executive relations in the regions, because both institutions had power. Article 14 paragraph (1) states that a Regional Representative Council (DPRD) is established as the Regional Legislature and Regional Government as Regional Executive Bodies. Meanwhile the Regional Government is only the Regional Head and other regional apparatus. The important thing from that is the position between the two institutions is equal and a partner.

The positive implication of the Law on Regional Autonomy relating to the position, function and rights of the Regional Representative Council, it is expected that Regional Representative Council, hereinafter mentioned as the council, to be more active in comprehending the aspirations that develop in the community, which then adopts it in various forms of public policy in the region together with the Regional Heads (Regents and Mayors). Another impact that later emerged in the context of regional autonomy was the demand for the government to create good governance as a prerequisite for the administration of the government by promoting accountability and transparency. To support accountability and transparency, good and accountable internal control and external control are needed. In connection with this, the role of the council is increasing in controlling government policy. According to Government Regulation (PP) Number 105 of 2000

Regarding the Management and Accountability of the Budget, it explains that: (1) Supervision of the budget is carried out by the council, (2) The Council has the authority to instruct external inspectors in the region to checks budget management. In general, the legislative body has three functions, namely: (1) the legislative function (the function of making legislation), (2) the budget function (the function to compile the budget, and (3) the supervisory function (function to supervise executive performance). In this research, the function of the council to be discussed was the budget supervisory function. The problem was whether in carrying out the supervisory function was more due to knowledge of the budget council or more due to other problems. In addition, whether public participation and transparency of public policy will also affect the budget supervision carried out by the council.

Budget supervision done by the council is influenced by internal factors and external factors (Pramono, 2002). Internal factors are factors that are owned by the council that directly influence the supervision carried out by the council, one of them is knowledge of the budget. While external factors are outside influences on the supervisory function by the council which indirectly influences the supervision carried out by the council, including the existence of public participation and transparency of public policy.

Similar research was conducted by [1] who concluded that budget knowledge had a significant influence on regional financial supervision conducted by the council. While Pramono (2002) states that the factors that hinder the function of supervision are the lack of qualified human resources (HR) and lack of facilities and infrastructure.

A research that examined whether public participation and public policy transparency will improve the supervisory function carried out by the council was conducted by Sopanah (2002). It was found that budget knowledge had a significant effect on the supervision of the 
APBD (Regional Government Budget) conducted by the council. It was also found that there was a relationship between the knowledge of budget and the participation of the community in the existence of a significant relationship to the supervision of the APBD (Regional Government Budget) conducted by the council. While the interaction of budget knowledge with public policy transparency did not significantly influence the supervision carried out by the council as there were no variables that can interact between budget knowledge and supervision conducted by the council. It make the writer is interested in re-examining the research of [1] and Sopanah (2002) which are expected to strengthen or weaken the relationship.

The Purpose of the Research

1. To provide empirical evidence that budget knowledge will influence the board in regional financial supervision APBK (District Government Budget)..

2. To provide empirical evidence that accountability will influence the relationship between budget knowledge and regional financial supervision APBK (District Government Budget).

3. To provide empirical evidence that community participation will influence the relationship between budget knowledge and regional financial supervision APBK (District Government Budget).

4. To provide empirical evidence that public policy transparency will influence the relationship between budget knowledge and regional financial supervision APBD (Regional Government Budget).

\section{Methodology}

\subsection{Regional Finance}

In Article 1 of PP. No. 105 of 2000 the definition of state finance is all regional rights and obligations within the framework of administering a government that can be assessed with money including all forms of wealth relating to the rights and obligations of the region within the framework of the APBD (Regional Government Budget). Understanding of the state finances are all state rights and obligations as well as everything related to these rights and obligations that can be valued with money (Baswir, 1999). From the definition of state finances mentioned above, the definition of regional finance is basically the same as the understanding of state finances in which the "state" is anologized by "regions". In this context, the regional finance is all regional rights and obligations that can be valued with money. Similarly, something both money and goods that can become regional wealth is related to the implementation of the rights of the obligation and of course within the limits of regional authority (Ichsan et.al, 1997).

\subsection{Regional Financial Supervision}

Supervision is needed to find out whether the plans that have been prepared can run efficiently, effectively and economically. Supervision according to Presidential Decree No. 74 of 2001 (Regarding Procedures for Supervision of Local Government Implementation) Article (16) states that the supervision of local government is a process of activities aimed at ensuring that the regional government runs in accordance with the plans and provisions of the prevailing laws and regulations. Supervision conducted by the council can be in the form of direct and indirect supervision and preventive and repressive. Direct supervision is carried out privately by observing, researching, examining, checking by yourself at the work site and 
requesting directly from the implementer by inspection. While indirect supervision is carried out by learning the reports received from the implementers. Preventive supervision is carried out through pre-audit, that is, before work begins. Repressive supervision is carried out through post-audit with an inspection of on-site implementation (inspection).

Supervision is an integral stage with all stages in the preparation and reporting of APBD (Regional Government Budget). Supervision is needed at each stage not only in the evaluation phase (Mardiasmo, 2001). The supervision carried out by the council begins during the process of preparing the APBD (Regional Government Budget), (Regional Government Budget) the APBD (Regional Government Budget), implementing the APBD (Regional Government Budget), and accountability of the APBD (Regional Government Budget). [2] states that the purpose of APBD (Regional Government Budget) supervision is to: (1) maintain the budget that is actually implemented, (2) keep the APBD (Regional Government Budget) implementation in accordance with the budget that has been outlined, and (3) keep the APBD (Regional Government Budget) implementation can be accounted for.

\subsection{Regional Financial Knowledge and Supervision}

In carrying out the functions and roles of council members, capacities and professions of the council are determined by the ability of bargaining positions in producing a policy. The capability and abilty of the council must be possessed include knowledge, skills and experience in drafting various regional regulations besides the council's expertise in politics representing the constituents and interests of the group and party. Some studies that examine the relationship between the quality of council members and their performance are carried out by (Indradi, 2001; [3];Sutamoto, 2002, Sopanah, 2002). The results of his research proved that the quality of the council was measured by education, knowledge, experience, and expertise influences the performance of the council, one of them is the performance during the supervision function. Education and training related to knowledge for the future.

Yudono (2002) said that (DPRD) Regional Representative Council would be able to use its rights appropriately, carry out its duties and obligations effectively and place its position proportionally if each member had sufficient knowledge in terms of technical conceptions of governance, public policy, and so on. The knowledge needed in conducting regional financial supervision is the knowledge about the budget. By knowing about the budget, it is expected that the council members can detect the waste and leakage of the budget.

\subsection{Accountability, Community Participation and Regional Financial Supervision}

The existence of a change in the budget paradigm in the reformation era requires public participation in the entire budget cycle. To create accountability to the public, it is necessary for the heads of agencies and citizens to participate in the preparation and supervision of the budget [4]. [5] states that community participation is the key to success of the implementation of regional autonomy because in participation concerning aspects of supervision and aspiration. The intended supervision here includes supervision of the executive through the legislative. The role of the council in supervising regional finances will be influenced by community involvement in budget advocacy. So, in addition to knowledge of the budget that affects the supervision carried out by the council, community participation is expected to improve the supervisory function In addition to accountability and community participation in the budget cycle, budget transparency is also needed to improve supervision. Transparency is one of the principles of good governance. Transparency is built on the basis of free information flow, the entire process of governance, institutions and information needs to be accessed by interested parties, and the information available must be sufficient to be understood and monitored.

The budget prepared by the executive is said transparent if it meets the following criteria: 
1. There is an announcement of budget policy.

2. Budget documents are available and are easily accessible.

3. Timely accountability reports are available.

4. The accommodation of people's votes / proposals.

5. There is a system of providing information to the public.

\section{Result and Discussion}

\subsection{Population and Sample}

The population in this study was the DPRK institution in Banda Aceh. The sample of this study was a council member in commission $\mathrm{C}$ because the commission is very closely related to the budget. Data was obtained by making a list of questions (questionnaires) made by Sopinah (2002), then the researchers developed it again according to the situation and related theories. The distribution of questionnaires was carried out directly (the questionnaire was delivered directly to the respondent concerned) for council members located in Banda Aceh City. Questionnaires were distributed as many as 30 copies because the number of board members on the budget commission in the Regional Representative Council in the city of Banda Aceh were 30 people. Before processing data, validity and reliability tests were performed before the data. This test was conducted to determine the accuracy and consistency of data collected from the use of measurements (Huck and Cormier, 1996; Hair, 1995). After validity and reliability tests were carried out, a classic assumption test consisted of: multicollinearity symptom testing, heteroscedasticity symptom testing, autocorrelation symptom testing, and data normality testing before data were further analyzed.

\subsection{Validity and Reliability Testing}

Research that measures variables using instruments in the questionnaire must be tested for quality on the data obtained by testing the validity and reliability. This test is aimed to determine whether the instrument used is valid and reliable because the correctness of the data that is processed determines the quality of the research results. Validity test aims to measure the quality of the instrument used, and shows the level of validity of an instrument, as well as how well a concept can be defined by a measure (Hair et al., 1998). The instrument is considered valid if the instrument has been able to measure what is desired and reveal the data that was examined appropriately. Testing is done by using factor analysis. Data that can be carried out factor analysis if Kaiser's MSA is above 0.5 (Kaiser \& Rice, 2974) and items included in factor analysis are items that have a factor loading above 0.40 (Chia, 1995).

Reliability testing is done by calculating cronbach alpha to test the feasibility of the consistency of all scales used. The instrument is considered reliable if it has a cronbach alpha more than 0.5 (Nunally, 1967).

\subsection{Identification and Measurement of Variable}

This research was designed as an empirical study. To test the proposed hypothesis, the variables studied need to be measured. The variables in this study can be grouped into two variables, namely independent variable and dependent variable. The independent variables in this study consist of: council knowledge about budget, community participation, accountability, and transparency of public policy. And as the dependent variable is regional financial supervision APBK (District Government Budget). All statistical calculations and analyzes are performed with SPSS for Windows version 10.0 software. 
1. Budget knowledge. Knowledge is respondents' perceptions of the budget (RAPBD / APBD) and detection of waste or failure, and budget leakage.

2. Community Participation. Community participation is the involvement of the community in every budgeting process activity carried out by the council when arranging directions and policies, determining strategies and priorities as well as budget advocacy.

3. Accountability. Accountability is the obligation of the trustee (council / agent) to provide accountability, present, report, and disclose all activities that are the responsibility of the trustee (community / principal) who has the right and authority to ask for such accountability.

4. Public Policy Transparency. Transparency of public policy is the openness of the budget that is easily accessible to the public. Public policy is an action taken by the government and as a decision that has a specific purpose.

5. Supervision of Regional Finance. Regional financial supervision is supervision carried out by the council which includes supervision at the time of drafting, ratifying, implementing, and budgeting APBD (Regional Government Budget)..

\subsection{Variable Measurement}

Each variable is measured by a Likert scale model that measures attitudes by agreeing or disagreeing with the question posed with a score of 5 ( $\mathrm{SS}=$ Strongly Agree), 4 ( $\mathrm{S}=$ Agree, 3 (TT = Don't Know, 2 (TS = disagree), and 1 (STS = Strongly Disagree).

\subsection{Analysis Method}

After the data was collected and tested for validity and reliability, then the testing was carried out which was related to the statistical model that was used in testing the hypothesis. The analytical tool to test the hypotheses used was multiple regression. Data processing was done with SPSS version 10 for windows. Hypothesis testing was carried out after the multiple regression model was used free from violations of classical assumptions, so that the test results can be interpreted correctly. The regression equation for testing hypotheses is as follows:

1. To test hypotheses $1\left(\mathrm{H}_{1}\right)$

$$
\begin{aligned}
& \mathrm{Y}=\alpha+\beta_{1} \mathrm{X}_{1}+\mathrm{e} \ldots \ldots \ldots \ldots . . . .(1) \\
& \text { Where : } \\
& \mathrm{Y}=\text { Regional Financial Supervision } \\
& \alpha \quad=\text { Constant }
\end{aligned}
$$

(APBD)

$\mathrm{X}_{1}=$ Coucil knowledge about budgeting

2. To test hypotheses $2(\mathrm{H} 2)$

$$
\begin{aligned}
& \mathrm{Y}=\alpha+\beta_{1} \mathrm{X}_{1}+\beta_{2} \mathrm{X}_{2}+\beta_{3} \mathrm{X}_{1} \mathrm{X}_{2}+\mathrm{e} \ldots \ldots \ldots \ldots \text { (2) } \\
& \text { Where : } \\
& \mathrm{Y} \quad=\text { Regional Financial Supervision } \\
& \alpha=\text { Constant } \\
& \mathrm{X}_{1} \quad \text { (APBD) Coucil knowledge about }
\end{aligned}
$$

$\mathrm{X}_{2}=$ Community Participation

$\mathrm{X}_{1}, \mathrm{X}_{2}, \quad=$ Interaction between

$$
\mathrm{X}_{1} \text { and } \mathrm{X}_{2}
$$

$\beta_{1} \beta_{2} \beta_{3}=$ Regression Coefficient

3. To test hypotheses $3(\mathrm{H} 3)$

Where

$$
\mathrm{Y}=\alpha+\beta_{1} \mathrm{X}_{1}+\beta_{4} \mathrm{X}_{3}+\beta_{5} \mathrm{X}_{1} \mathrm{X}_{3}+\mathrm{e} .
$$

$\mathrm{Y}=$ Regional Financial Supervision (APBD)

$\mathrm{X}_{3}=$ Accountabilty

$\mathrm{X}_{1}, \mathrm{X}_{3}=$ Interaction between $\mathrm{X}_{1}$ and $\mathrm{X}_{3}$ 
B1 $\beta 4 \beta 5=$ Regression Coefficient

4. To test hypotheses s 4 (H4)

$$
\begin{aligned}
& \mathrm{Y}=\alpha+\beta_{1} \mathrm{X}_{1}+\beta_{6} \mathrm{X}_{4}+\beta_{7} \mathrm{X}_{1} \mathrm{X}_{4}+\quad \mathrm{e} \ldots .(4) \\
& \text { Where: } \\
& \mathrm{Y}=\text { Regional Financial Supervision } \\
& \text { (APBD) } \\
& \mathrm{X}_{4}=\text { Public Policy Tranperency } \mathrm{X}_{1}, \mathrm{X}_{4}=\text { Interaction between } \mathrm{X}_{1} \text { and } \mathrm{X}_{4} \mathrm{~B}_{1}, \beta_{6}, \beta_{7}=
\end{aligned}
$$

In Article 1 of PP. No. 105 of 2000 the definition of state finance is all regional rights and obligations within the framework of administering a government that can be assessed with money including all forms of wealth relating to the rights and obligations of the region within the framework of the APBD (Regional Government Budget).. The definition of state finances are all state rights and obligations as well as everything related to these rights and obligations that can be valued with money (Baswir, 1999).

From the definition of state finances mentioned above, the definition of regional finance is basically the same as the understanding of state finances in which the "state" is anologized by "regions". In this context, the regional finance is all regional rights and obligations that can be valued with money. Similarly, something both money and goods that can become regional wealth is related to the implementation of the rights of the obligation and of course within the limits of regional authority (Ichsan et.al, 1997).

Associated with accountability for the use of budgets, community is also actively involved in monitoring where the community is always included in budget supervision, because budget monitoring is needed to find out whether the plans that have been prepared can run efficiently. Supervision carried out by council members is in the form of direct and indirect supervision by examining, checking, and ways of infection.

In addition, the knowledge, experience and expertise have a big influence on the performance of the members of the council, one of them is the function of supervision, training, which is of course related to future knowledge. Sopanah (2002) states that the DPRK will be able to use its rights appropriately, carry out its duties and obligations effectively and place its position proportionally if each member of the council has sufficient knowledge in terms of technical conception of the administration of local governance, public policy, knowledge needed in monitoring the regional financial budget, one of them is budget knowledge, it is expected that the council members can detect the budget waste and leakage.

\section{Conclusion}

Based on the results of data analysis and discussion obtained in the study, it can be concluded that: Describing that all members of the council responded positively to accountability, public participation and transparency, so that the community always had openness between the community and the legislative members.

\section{References}

[1] R. Andriani, "Effect of Knowledge and RPPs on the Role of Regional Representative Council in Bengkulu Province.” Bengkulu, 2002.

[2] Alamsyah, "APBD Supervision Mechanism in Sleman Regency.” Yogyakarta, 1997.

[3] S. Sjamsudin, "The Relationship of the Quality of Regional Representative Council Members to 
their Participation in the Regional Policy Process in Malang Regency," 2001.

[4] I. Rubin, Budgeting for Accountability: Municipal Budgeting for the 1990s. Public Budgetting \& Finance Journal, Summer, 1996.

[5] A. Achmadi, M. Muslim, S. Rusmiyatri, and Sonny, "Good Governance and Strengthening Regional Institutions, Indonesian Transparency Society.” Jakarta, 2002. 